\title{
Some aspects of obesity in childhood
}

\author{
Olga Stark and June K. Lloyd
}

Institute of Child Health (University of London), 30 Guilford Street, London WC1N 1EH, UK.

In 1950 Otto Wolff set up one of the first clinics in the United Kingdom specifically for the study and treatment of obesity in children. His original observations on the effects of over-nutrition on the development of children and of the outcome of hospital treatment (Wolff, 1955; Lloyd et al., 1961) have never been surpassed. His continuing interest in the subject has promoted work into many aspects - cellular, biochemical, psychological and epidemiological - and, together with the studies of numerous workers in many countries, has greatly enhanced our knowledge of this important nutritional disorder. Nevertheless many questions wait for answers and many problems for solutions. This review will discuss some of them. Because obesity in children is only rarely associated with endocrine diseases or other syndromes, these will not be considered here and the topic remains that of 'simple obesity' - in itself a grave misnomer!

\section{Definition}

Obesity may be defined as a condition of excess body fat but, because it is not known by exactly how much body fat has to be increased in order to be harmful to health, there is no precise or agreed definition.

The assessment of obesity has to rely on indirect measurements and although laboratory procedures (such as estimation of lean body mass by ${ }^{40} \mathrm{~K}$ determination) are probably more accurate than anthropometry, for practical reasons anthropometric measures such as skinfold thickness and weight for height are normally used. A child whose weight is more than $20 \%$ above the standard weight for height, age and sex is generally considered to be obese (Wolff, 1966), and this definition is also frequently used in adults in whom it is linked with increased mortality rates (Report of the Royal College of Physicians of London, 1983). Alternatively, those children whose weight for height or skinfold thickness is above one of the upper centiles on growth charts (85th; Dietz \& Gortmaker, 1985, or 90th; Morris \& Chinn, 1981), may be defined as obese. Studies comparing estimates of total body fat obtained by laboratory procedures with those based on measurement of various skinfolds

Correspondence: Olga Stark, M.D. or on weight for height data, have, in general, shown slightly better correlations between skinfolds and laboratory estimates, than between weight for height and such measurements (Dugdale \& Griffiths, 1979; $\mathrm{Ku}$ et al., 1981; Roche et al., 1981).

In practice most clinical and epidemiological studies of obesity use measurements of weight and height. One of the reasons for this may be that few people have been trained to use skinfold calipers while weight and height are more routinely measured. Furthermore, in some grossly obese patients skinfolds cannot be measured accurately (Bray et al., 1978). It is important to recognize that children identified as obese by weight criteria are not always the same children as those identified by a skinfold method (Morris \& Chinn, 1981). A diagnosis of obesity is also often made by visual inspection during a clinical examination and this method is commonly used by parents, teachers and nurses. Such visual diagnosis may, however, differ from that derived from weight for height (C. Moynihan, unpublished observation) or skinfold criteria, particularly in borderline cases, and because it cannot be quantified it is rarely used in systematic studies.

\section{Prevalence among British children}

Obesity is a common nutritional disorder among British children. In the national cohort of children born in 1958 (The National Child Development Study, NCDS, Peckham et al., 1983), the estimated prevalence of obesity (defined by weight for height, age and sex criteria) at the age of 7 was $4 \%$ in boys and $6 \%$ in girls, rising to $7 \%$ and $10 \%$ during adolescence.

In view of the different methods of defining obesity it is not surprising that it has not been satisfactorily established whether the prevalence of childhood obesity in Britain has changed during years of economic affluence. Howard et al. (1971) measured weight and height in school children from Leicester between 1962 and 1969 and recorded a prevalence of around $2.5 \%$ without any evidence for an increasing trend. On the other hand, Colley (1974) compared skinfold thickness in school children from Aylesbury in 1971 with those of London children in 1951 and found an increased prevalence of obesity among the girls in 1971 though not among the boys. Durnin et al. (1974) found 
that 14 year old boys attending Glasgow schools in 1971 had higher values of skinfold thickness than those measured in 1964 although their heights and weights were similar. No difference was found between girls. When children born in 1958 were compared with those born in 1946 (Peckham et al., 1983) twice as many 7 year olds born in 1958 were obese as those born 12 years earlier, but by adolescence the difference between the two populations had almost disappeared. Thus there is no convincing evidence that obesity has become much more prevalent among older children although information about the current generation of children is scarce. In assessing prevalence data it must be remembered that there is geographical variation (C.S. Peckham, unpublished observations) and that social class (Peckham et al., 1983) and ethnic origin (Garn \& Clark, 1976), are important contributory factors.

\section{Obesity in infancy}

The high incidence of obesity in babies in the early seventies attracted much attention. Shukla et al. (1972) found that $17 \%$ of 300 infants studied in Dudley were obese and a further $28 \%$ were overweight. She defined 'obese' as over $20 \%$ above expected weight, and 'overweight' as between $10-20 \%$ above expected weight. This study and several others (Fomon et al., 1975; Taitz, 1971) implied that artificial infant feeding regimes and the early introduction of solids resulted in overfeeding with consequent obesity. A review of infant feeding practices in 1974(Department of Health and Social Security, 1974) emphasized the importance of breast feeding, the correct composition and reconstitution of formula feeds, and the later introduction of solids. By 1980 it was clear that infant feeding practices had improved and it appeared that the prevalence of excessive weight gains in infancy had decreased (Department of Health and Social Security, 1980). Skinfold thickness in infants measured in London in 1976 was less than that in infants from Derbyshire measured in 1967 (Whitelaw, 1977).

The experience from this period needs to be interpreted with caution. To what extent 'overfeeding' may contribute to obesity in infancy is still not clear. A number of studies have failed to find significant differences between the weight of infants who were breast fed or bottle fed whether or not they were given solids (Davies et al., 1977; de Swiet \& Fayers, 1977). Furthermore it has not been possible to show that heavy infants 'overeat' in comparison with infants of average or below average weight (Dubois et al., 1979; Mumford \& Morgan, 1982). The ability to predict either weight or skinfold thickness at the age of 12 months is limited. In a detailed study of $\mathbf{4 6 2}$ full term infants in Montreal (Kramer et al., 1985) only sex, birth weight, duration of breastfeeding, and age at introduction of solids were related to the weight at 12 months and these variables explained only $30 \%$ of the variance in weight.

\section{Risk of obesity persisting in later life}

The contribution of infant obesity to obesity later in life is probably modest. Only $3(10 \%)$ out of 28 obese, and $2(1 \%)$ out of 175 non-obese, infants from Dundee were obese at the age 4- 5 years (Poskitt \& Cole, 1977); many other studies have also shown that although an overweight infant is more likely to be overweight as a child or adult than is an infant of 'normal weight', most fat babies do not remain obese (Asher, 1966; Charney et al., 1976; Eid, 1970; Mack \& Ipsen, 1974; Mellbin \& Vuille, 1976; Jaffe \& Kosakov, 1982).

Skinfold thickness measurements in children less than 2 years of age have been shown to have no predictive value for skinfold thickness in preadolescent or adolescent children. After the age of 2 years, there is increasing correlation between skinfold measurements at different ages (Hawk \& Brook, 1979; Owen, 1982; Roche et al., 1982). In general, heavier children of any age are more likely to be obese later in life (Fisch et al., 1975; Johnston \& Mack, 1978; Spyckerelle et al., 1985). In the NCDS (Peckham et al., 1983) the risk of being more than $20 \%$ overweight in adolescence was as low as 2 in 100 for a 7 year old whose weight for height was below average but for a child more than $30 \%$ overweight it was greater than 6 in 10. The risk for children attending special obesity clinics (Lloyd et al., 1961) may be higher than that for obese children in the general population because most children referred to hospital are severely overweight.

Obesity is much more common in adult life than in childhood and most obese adults are unlikely to have been obese in early childhood. In the longitudinal study by Stark et al. (1981) only $7 \%$ of 26 year old obese men and $13 \%$ of women had been obese at 7 years; the proportions had, however, increased to $28 \%$ and $45 \%$ respectively for obesity at 14 years.

\section{Aetiology of obesity}

No single theory is likely to explain why some people become fat whilst others remain lean. The direct cause of obesity is an energy intake in excess of requirements and the subsequent storage of this excess in the form of body fat. Obese children and adults do not appear to have higher food intake or expend less energy in physical activity than their lean peers (Jung \& James, 1980). Defects in thermogenesis have been propounded and enjoy current popularity but the evidence for their role in human obesity remains inconclusive 
(Garrow, 1983; Report of the Royal College of Physicians, 1983). The search for a cause of obesity has also included studies of hypothalamic control of feeding behaviour (Hernandez \& Hoebel, 1980), of adipose tissue cellularity (Sjöström, 1980), of body weight set points (Keesey, 1980), and of psychological aspects (Mitchell, 1980; Rodin, 1981), but again without definitive results.

\section{Family factors}

Genes and environment undoubtedly interact within families. The risk of obesity among children is lowest when neither parent is obese, higher when one parent is obese, and highest when both parents are obese. Garn \& Clark (1976) found considerable familial resemblance for obesity between parents and offspring $(r=0.30)$ and between siblings $(r=0.40)$. The relative importance of the effect of family environment and heredity on obesity in children aged 4-11 was investigated by Hartz et al. (1977) using data from almost 11,000 families in the USA and showed that the environment accounted for $32 \%$ of the variation in obesity in the children. The estimated heritability index (which represents the estimate of the proportion of variation in obesity attributable to genetic factors) was only $11 \%$ in this study. Brook et al. (1975), in a study of twins, reported a heritability index for subscapular and triceps skinfolds of 0.52 for twins under 10 years old, and of 0.98 for those over 10 years of age. The wide range of the heritability index $(0.30-0.98)$ for weight, overweight, or skinfolds found in other twin studies may be explained by various factors such as age, environment or size of the sample (Foch \& McClearn, 1980).

An attempt to assess the relative importance of various factors to the origin of obesity in Swedish school children was made by Vuille \& Mellbin (1979). They concluded that no single predictor or category of predictors came out as entirely dominant and this supports the multifactorial hypothesis. In 10 year old girls heredity and activity seem to be more prominent whereas appetite and environmental conditions are of greater importance in boys.

The emotional relationship between mother and child and, in particular, their interactions concerning the nature of food, probably plays an important role in the development of childhood obesity (Bruch, 1974). An obese child may not learn to discriminate between hunger and emotional stress and overeat in response to emotional upsets. Direct observational studies of 37 families with an obese child (together with suitable controls) have recently been made at the Institute of Child Health in London. Preliminary findings suggest that childhood obesity may indeed be a 'family symptom' (W. Kinston, personal communication). It was associated with a specific pattern of interaction amongst family members, and the families expressed characteristic experiences, beliefs, and attitudes about obesity and eating.

Socioeconomic conditions and education also play their part. In the National Child Development Study (Peckham et al., 1983) girls from a lower social class were more likely to be obese than those from a higher class; a similar difference was present in the boys though not statistically significant. In the British population the effect of social class appears to be less important in early childhood than in adolescence and adult life when again the lower social groups are more likely to be obese (O. Stark, unpublished observations).

In an affluent society most families can afford to eat as much as they wish. Meals are prepared with the aim of giving pleasure rather than satisfying hunger and nutritional needs, and various social functions encourage overeating. The palatability of a food rather than energy needs usually determines the amount of the food consumed. As the need for physical work and walking has generally declined so time for leisure has increased. Eating behaviour is clearly influenced by these factors but their role in the development of obesity is difficult to assess. Television viewing may have a considerable influence for children; in the USA a significant positive association was found between the time spent watching television and the prevalence of obesity observed in 6-17 year olds (Dietz \& Gortmaker, 1985).

\section{Effects}

The effects of obesity are largely related to its degree. A slightly obese child probably does not suffer from the consequences of being obese except for some increased risk of obesity in later life.

With increasing fatness the number of problems related to the obesity also increase. For children the social and psychological consequences are the most serious. An obese child is frequently teased and ostracised by his peers (Wolff, 1962) and may be disliked even more than frankly disabled or disfigured children. This often results in feelings of unworthiness, poor self image and lack of self confidence. Participation in play, sports and other activities, may be reduced for both physical and psychological reasons.

Obese children are frequently tall for their age, mature early (Wolff, 1955), and may be more susceptible to respiratory problems (Somerville et al., 1984). Raised blood pressure, impaired glucose tolerance, and hyperlipidaemia are amongst the complications which are usually reversed by weight reduction (Lloyd $\&$ Wolff, 1976). Only extreme degrees of obesity are likely to be complicated by the rare 'Pickwickian 
syndrome' (hypoventilation, somnolence and heart failure).

\section{Treatment}

Reduction in energy intake by food restriction, combined with encouragement of energy expenditure by exercise remains the most widely used form of treatment. Some obese children respond well to dietary restrictions introduced by parents, or recommended by family or school doctors, or dieticians, and may achieve and maintain near normal weight for their age and height. As these children seldom reach special clinics little is known about them as a group either in terms of their characteristics or natural history.

Most children seen in hospital clinics prove refractory to treatment in the long term and hospital admission for weight reduction does not appear to improve the ultimate prognosis in the majority (Stark et al., 1975). Long term results are unrelated to the rate of weight loss achieved during treatment (Wolff, 1962).

Little is known about whether children benefit more from any particular 'type' of diet. The regime will be more acceptable if adjusted according to the age of the child, the duration and severity of the obesity, the emotional status, eating habits and family environment. Very low energy diets of $200-600 \mathrm{kCal} / \mathrm{day}$, or 'protein sparing fasting' remain controversial for the treatment of children (Taitz, 1983). The use of anorectic drugs in children is discouraged (Lloyd \& Wolff, 1976). Surgical treatment may be considered in morbidly obese adolescents in whom all conventional measures have failed. The expected benefit must be carefully weighed against the complications of surgery and long term metabolic problems. The operation and follow-up should be carried out in a centre which has experience with this form of treatment.

A low energy diet may cause a fall of metabolic rate and thus a gradually decreasing rate of weight loss on the same calorie intake. Increased physical activity may compensate for a lower metabolic rate and improve weight loss. Physical activity is generally beneficial for all children but the obese rarely enjoy it and should not be asked to participate in activities they dislike or are ridiculed in. Behaviour modification

\section{References}

ASHER, P. (1966). Fat babies and fat children. Archives of Disease in Childhood, 41, 672.

BRAY, G.A., GREENWAY, F.L., MOLITCH, M.E., DAHMS, W.T., ATKINSON, R.L. \& HAMILTON, K. (1978). Use of anthropometric measures to assess weight loss. American Journal of Clinical Nutrition, 31, 769.

BROOK, C.G.D., HUNTLEY, R.M. \& SLACK, J. (1975). techniques and parental participation may improve the short term results of treatment. In a review by Brownell \& Stunkard (1980) it was concluded that 'behaviour therapy has great promise in the treatment of obesity but long term maintenance of clinically significant weight loss is still elusive'.

\section{Prevention}

The recent report of the Royal College of Physicians of London (1983) states that 'very little work has been undertaken to identify the best method for preventing excessive weight gains in either childhood or in adult life'.

It is possible that early identification of young obese children and, more especially, of those who are at risk of becoming obese would provide an opportunity to influence their future development. Parents could be advised individually about suitable diets, ways to influence eating habits, and the importance of physical activity. Health education for school children should include practical aspects of nutrition, choice of foods and ways of preparation.

Trials of regular screening for obesity at school clinics and the introduction of special programmes of dietary counselling and physical activity would be valuable, but have to be set against what is known of the natural history of obesity in childhood at various ages. The prevention of obesity in children cannot be considered in isolation from the problem in the community as a whole.

\section{Conclusion}

The comments of Rodin (1981) apply to children as well as to adults: 'Genetic, metabolic, psychological, and environmental factors are associated with obesity. Some of them may cause, others may serve to maintain or enhance obesity. Many interact with one another. Obesity is almost certainly not a single syndrome, has not a single cause and probably has not a single cure'. The work on childhood obesity so steadfastly pursued by Otto Wolff over the past 35 years will undoubtedly continue for many more to come.

Influence of heredity and environment in determination of skinfold thickness in children. British Medical Journal, 2, 719.

BROWNELL, K.D. \& STUNKARD, A.J. (1980). Behavioural treatment for obese children and adolescents. In Obesity, Stunkard, A.J. (ed). p.415. W.B. Saunders Company: Philadelphia. 
BRUCH, H. (1974). In Eating Disorders: Obesity, Anorexia Nervosa and the Person Within p.56. Routledge and Kegan Paul: London.

CHARNEY, E., CHAMBLEE GOODMAN, H., McBRIDE, M., LYON, B. \& PRATT, R. (1976). Childhood antecedents of adult obesity. New England Journal of Medicine, 295, 6.

COLLEY, J.R.T. (1974). Obesity in schoolchildren. British Journal of Preventive Social Medicine, 28, 221.

DAVIES, D.P., GRAY, O.P., ELWOOD, P.C., HOPKINSON, C. \& SMITH, S. (1977). Effect of solid foods on growth of bottle fed infants in first three months of life. British Medical Journal, 2, 7.

DEPARTMENT OF HEALTH AND SOCIAL SECURITY, London (1974). Present-day practice in infant feeding.

DEPARTMENT OF HEALTH AND SOCIAL SECURITY, London (1980). Present-day practice in infant feeding.

DE SWIET, M. \& FAYERS, P. (1977). Effect of feeding habit on weight in infancy. Lancet, $\mathbf{i}, 892$.

DIETZ, W.H. \& GORTMAKER, S.L. (1985). Do we fatten our children at the television set? Obesity and television viewing in children and adolescents. Pediatrics, 75, 807.

DUGDALE, A.E. \& GRIFFITHS, M. (1979). Estimating fat body mass from anthropometric data. American Journal of Clinical Nutrition, 32, 2400.

DUBOIS, S., HILL, D.E. \& BEATON, G.H. (1979). An examination of factors believed to be associated with infantile obesity. American Journal of Clinical Nutrition, 32, 1997.

DURNIN, J.V.G.A., LONERGAN, M.E., GOOD, J. \& EWAN, A. (1974). A cross-sectional nutritional and anthropometric study, with an interval of 7 years, on 611 young adolescent schoolchildren. British Journal of Nutrition, 32, 169.

EID, E.E. (1970). Follow up study of physical growth of children who had excessive weight gain in the first 6 months of life. British Medical Journal, 2, 74.

FISCH, R.O., BILEK, M.K. \& ULSTROM, R. (1975). Obesity and leanness at birth and their relationship to body habitus in later childhood. Pediatrics, 56, 521.

FOCH, T.T. \& MCCLEARN, G.E. (1980). Genetics, body weight and obesity. In Obesity, Stunkard, A.J. (ed). p. 60. W.B. Saunders Co.: Philadelphia.

FOMON, S.J., FILLER, L.J., THOMAS, L.N., ANDERSON, T.A. \& NELSON, S.E. (1975). Influence of formula concentration on calorie intake and growth of normal infants. Acta Paediatrica Scandinavica, 64, 172.

GARN, S.M. \& CLARK, D.C. (1976). Trends in fatness and the origins of obesity. Pediatrics, 57, 443.

GARROW, J.S. (1983). Luxuskonsumption, brown fat and human obesity. British Medical Journal, 286, 1684.

HARTZ, A., GIEFER, E. \& RIMM, A.A. (1977). Relative importance of the effect of family environment and heredity on obesity. Annals of Human Genetics London, 41, 185.

HAWK, L.J. \& BROOK, C.G.D. (1979). Influence of body fatness in childhood on fatness in adult life. British Medical Journal, 1, 151.

HERNANDEZ, L. \& HOEBEL, B.G. (1980). Basic mechanism of feeding and weight regulation. In Obesity, Stunkard, A.J. (ed). p. 25. W.B. Saunders Co.: Philadelphia.

HOWARD, A.N., DUB, I. \& McMAHON, M. (1971). The incidence, cause and treatment of obesity in Leicester school children. The Practitioner, 207, 662.

JAFFE, M. \& KOSAKOV, C. (1982). The motor development of fat babies. Clinical Pediatrics, 21, 619.
JOHNSTON, F.E. \& MACK, R.W. (1978). Obesity in urban black adolescents of high and low relative weight at 1 year of age. American Journal of Disease in Childhood, 132, 862.

JUNG, R.T. \& JAMES, W.P.T. (1980). Obesity: is obesity metabolic? British Journal of Hospital Medicine, 24, 503.

KEESEY, R.E. (1980). A set-point analysis of the regulation of body weight. In Obesity, Stunkard, A.J. (ed). p. 144. W.B. Saunders Co.: Philadelphia.

KRAMER, M.S., BARR, R.G., LEDUC, D.G., BOISJOLY, C., MCVEY-WHITE, L. \& PLESS, I.B. (1985). Determinants of weight and adiposity in the first year of life. Journal of Pediatrics, 106, 10.

KU, L.C., SHAPIRO, L.R., CRAWFORD, P.B. \& HUENEMANN, R.L. (1981). Body composition and physicial activity in 8year-old children. American Journal of Clinical Nutrition, 34, 2770.

LLOYD, J.K., WOLFF, O.H. \& WHELEN, W.S. (1961). Childhood obesity. A long-term study of height and weight. British Medical Journal, 2, 145.

LLOYD, J.K. \& WOLFF, O.H. (1976). Obesity. In Recent Advances in Paediatrics. Hull, D. (ed). p. 305. Churchill Livingstone: Edinburgh, London and New York.

MACK, R.W. \& IPSEN, J. (1974). The height-weight relationship in early childhood. Birth to 48 month correlations in an urban, low-income negro population. Human Biology, 46, 21.

MELLBIN, T. \& VUILLE, J.-C. (1976). Weight gain in infancy and physical development between 7 and $10 \frac{1}{2}$ years of age. British Journal of Preventive Social Medicine, 30, 233.

MITCHELL, E.M. (1980). Obesity: psychological aspects and management. British Journal of Hospital Medicine, 24, 523.

MORRIS, R.W. \& CHINN, S. (1981). Weight-for-height as a measure of obesity in English children five to 11 years old. International Journal of Obesity, 5, 359.

MUMFORD, P. \& MORGAN, J.B. (1982). A longitudinal study of nutrition and growth of infants initially on the upper and lower centile for weight and age. International Journal of Obesity, 6, 335.

OWEN, G.M. (1982). Measurement, recording, and assessment of skinfold thickness in childhood and adolescence: report of a small meeting. American Journal of Clinical Nutrition, 35, 629.

PECKHAM, C.S., STARK, O., SIMONITE, V. \& WOLFF, O.H. (1983). Prevalence of obesity in British children born in 1946 and 1958. British Medical Journal, 286, 1237.

POSKITT, E.M.E. \& COLE, T.J. (1977). Do fat babies stay fat? British Medical Journal, $1,7$.

REPORT OF THE ROYAL COLLEGE OF PHYSICIANS (1983). Obesity. Journal of The Royal College of Physicians of London, 17, 5.

ROCHE, A.F., SIERVOGEL, R.M., CHUMLEA, W.C. \& WEBB, P. (1981). Grading body fatness from limited anthropometric data. American Journal of Clinical Nutrition, 34, 2831.

ROCHE, A.F., SIERVOGEL, R.M., CHUMLEA, W.C., REED, R.B., EICHORN, D. \& MCCAMMON, R.M. (1982). Serial changes in subcutaneous fat thicknesses of children and adults. In Monographs in Paediatrics, Falkner, F., Kretchmer, N. \& Rossi, E. (eds). S. Karger: Basel, Munchen, Paris, London, New York and Sydney.

RODIN, J. (1981). Current status of the internal-external hypothesis for obesity: What went wrong? American Psychologist, 36, 361. 
SHUKLA, A., FORSYTHE, H.A., ANDERSON, C.M. \& MARWOK, S.M. (1972). Infantile overnutrition in the first year of life. A field study in Dudley, Worcestershire. British Medical Journal, 4, 507.

SJÖSTRÖM, L. (1980). Fat cells and body weight. In Obesity, Stunkard, A.J. (ed). p. 72. W.B. Saunders Co.: Philadelphia.

SOMERVILLE, S.M., RONA, R.J. \& CHINN, S. (1984). Obesity and respiratory symptoms in primary school. Archives of Disease in Childhood, 59, 940.

SPYCKERELLE, Y., PETIT, J.C., GUEGUEN, R., ANDRE, J.L. \& DESCHAMPS, J.P. (1985). Evolution a 5 ans de la corpulence chez les enfants et les adolescents. Archives Francaises de Pediatrie, 42, 81.

STARK, O., LLOYD, J.K. \& WOLFF, O.H. (1975). Long-term results of hospital in-patient treatment of obese children. Recent Advances in Obesity Research: 1 (Proceedings of the First International Congress on Obesity), Howard, A. (ed). p. 289. Newman Publishing Co: London.

STARK, O., ATKINS, E., WOLFF, O.H. \& DOUGLAS, J.W.B.
(1981). Longitudinal study of obesity in the National survey of health and development. British Medical Journal, 283, 13.

TAITZ, L.S. (1971). Infantile overnutrition among artificially fed infants in the Sheffield region. British Medical Journal, 1, 315.

TAITZ, L.S. (1983). Radical treatment for profound obesity. In The Obese Child. p. 224. Blackwell Scientific Publications: Oxford.

VUILLE, J.-C. \& MELLBIN, T. (1979). Obesity in 10-year-olds: An epidemiologic study. Pediatrics, 64, 564.

WHITELAW, A. (1977). Infant feeding and subcutaneous fat at birth and one year. Lancet, ii, 1098.

WOLFF, O.H. (1955). Obesity in childhood. A study of the birth weight, the height and the onset of puberty. Quarterly Journal of Medicine, 24, 109.

WOLFF, O.H. (1962). Obesity in childhood and its effects. Postgraduate Medical Journal, 38, 629.

WOLFF, O.H. (1966). Obesity in childhood. Triangle: The Sandoz Journal of Medical Science, 7, 234. 